\title{
Nutritional Evaluation of Dietary Proteins with Regard to Body Protein Metabolism in Adult Rats Using Purified Whole Egg Protein as a Standard Reference
}

\author{
Michio Yamaguchi and Makoto Kandatsu* \\ Department of Agricultural Chemistry, Faculty of Agriculture, University of Tokyo \\ Received September 7, 1972
}

\begin{abstract}
A new method for the preparation of whole egg protein was presented and its qualification as a standard reference for evaluating dietary protein was made in the course of this experiment: e.g., Purity, 96.5\% and Biological value, 99.9. The amino acid composition was almost identical with that shown in the table of FAO (1970).

Using this whole egg protein, casein and yeast, the nutritive values of dietary proteins in the adult rats at the normal level of body protein and in those after 8 day's protein depletion were compared. It was found that the evaluation after protein depletion had a tendency to overestimate the nutritive value of proteins rather making the difference little between each other. The significance of the relative evaluation by use of the purified whole egg protein was discussed with special regard to the actual retention of body nitrogen, i.e., the net nitrogen retention.
\end{abstract}

Many biological methods have been applied to the nutritional evaluation of dietary protein $^{11}$ and some of them such as Protein efficiency ratio (PER), Biological value (BV) and Net protein utilization (NPU) seem to be almost established as a routine method but with considerable differences in the assay condition and in the way of calculation between workers. All these methods are mostly based on the changes in body weight and nitrogen balance at definite levels of dietary protein, and the values are usually expressed as efficiency.

Apart from the discrepancy in methodology, there still remain some problems: e.g., to what extent those values represent the nutritional significance for protein metabolism of animals. Because, the measurements have been made, in most cases, under the specified conditions that are generally considered to enlarge the sensitivity of assay, and the results have not been strictly discussed in reference to the actual level of body protein and also of the metabolic activities of body protein itself. As has been reported the evaluation of dietary protein in the adult animals could vary with

* Present address: Azabu Veterinary College. the magnitude of protein reserves.

On the other hand, some trials of reference protein for making a relative evaluation of dietary protein have been made using the standard casein or egg protein. But, there seem to be no preferable standard protein which is easily preparable and secures the maximum nutritive value hitherto obtained. It is naturally desirable that the reference protein has a well-balanced amino acid composition with little variance.

This study presented a simple procedure for the preparation of purified whole egg protein and made a comparison in adult rats between the nutritive values of dietary proteins for maintaining the normal level of body protein and those for recovering the 8 day's protein depletion of the animals using the prepared whole egg protein as a standard reference.

\section{MATERIALS AND METHODS}

Preparation of whole egg protein. The whole egg protein was prepared by a new method which consisted of the separation of protein by coaguration with hot ethanol and the elimination of impurities by the succesive extractions with hot water, acetone and 
ethyl ether. An example of the preparation was as follows: Forty-four fresh commercial hen's eggs weighing $2,545 \mathrm{~g}$ were broken, and their yolk and white were taken in a 5 liter flask. After vigorous beating with a glass rod to crush the yolk, 3 liters of ethanol was added and well mixed. The mixture was steamheated stirring at intervals to coagulate the egg protein. After 20 min' boiling it was transfered into a cloth bag and the liquor was filtered through the cloth. The filtrate which contains the majorities of moisture and fat was discarded. The coagulated protein with a little yellowish color was again treated with 2 liters of ethanol in the same way. In order to remove the concomitant sugars and minerals, the sample was then twice extracted with 3 liters of hot distilled water in the same flask by steam-heating for $30 \mathrm{~min}$, the resulting turbid extract being filtered off through the cloth of bag. The next extraction for the residue was conducted with 1.5 and 1 liters of acetone in succession in the same flask to remove water and fat, the extract being again discarded by filtration through the cloth of bag. The final extraction for the residue with 1 liter of ethyl ether for complete elimination of fat was done twice in the same way. The sample which colored almost white was dried in an oven under $80^{\circ} \mathrm{C}$. In all the processes, care was taken to make the coagulated protein as small pieces as possible by hand covered with rubber glove and also to squeeze it powerfully to eliminate concomitant impurities effectively.

The protein weighed $283 \mathrm{~g}$ and its recovery against the true protein of the original eggs was $95 \%$. The nitrogen content determined by the Kjeldahl method was $15.57 \%$ on dry basis, equivalent to $96.5 \%$ of protein content provided that the protein factor of nitrogen is 6.25 . The crude ash content determined by a routine method was $2.4 \%$. The amino acid composition together with amide nitrogen is shown in Table I. The amino acid analysis was made by column chromatography using the Shibata Model AA-600 Amino Acid Analyzer, where methionine and cystine were transfered in advance to their oxidized forms with performic acid by the method of Moore.2) Tryptophan was analysed by the microbiological method using Lactobacillus arabinosus 17-5, ATCC 8014 and the DIFCO assay medium, 0327-15 BACTO. ${ }^{3 !}$ Amide nitrogen was determined by the method of Bailey."

The purity of the whole egg protein is considered to be highest among those hitherto used as protein source in nutritional experiments, and the amino acid composition was almost similar to that of whole egg listed in the table of FAO. ${ }^{5}$ ) The content of amide nitrogen showed that the approximate molar ratio of amide-form amino acids (glutamine and asparagine) to the corresponding dicarboxylic amino acids (glutamic acid and aspartic acid) was 1:4.
Table I. Amino Acid Composition of the Prepared Whole Egg Protein

\begin{tabular}{lc}
\hline Essential amino acid ${ }^{a /}$ & $(\mathrm{g} / 16 \mathrm{~g} \mathrm{~N})$ \\
\hline Histidine & $2.42 \pm 0.12^{b /}$ \\
Isoleucine & $5.79 \pm 0.21$ \\
Leucine & $9.03 \pm 0.30$ \\
Lysine & $7.09 \pm 0.52$ \\
Methionine & $3.45 \pm 0.20$ \\
Cystine & $2.05 \pm 0.09$ \\
$\quad$ (Total) & $(5.50 \pm 0.19)$ \\
Phenylalanine & $5.54 \pm 0.26$ \\
Tyrosine & $4.26 \pm 0.32$ \\
$\quad$ (Total) & $(9.80 \pm 0.57)$ \\
Threonine & $4.84 \pm 0.14$ \\
Valine & $6.73 \pm 0.32$ \\
Tryptophan & $\mathbf{1 . 4 9 \pm 0 . 0 3}$ \\
Arginine & $6.46 \pm 0.43$ \\
$\quad$ (Total) & $(59.15)$ \\
\hline
\end{tabular}

\begin{tabular}{lr}
\hline Nonessential amino acid & \\
\hline Aspartic acid & $10.07 \pm 0.30$ \\
Serine & $7.72 \pm 0.34$ \\
Glutamic acid & $13.40 \pm 0.34$ \\
Proline & $4.02 \pm 0.14$ \\
Glycine & $3.39 \pm 0.09$ \\
Alanine & $5.99 \pm 0.16$ \\
$\quad$ (Total) & $(44.59)$ \\
Total & 103.74 \\
\hline Amide N & $2.76(\%$ of total N) \\
\hline a) For rat & \\
b) Standard deviation &
\end{tabular}

Animals and diets. Eighteen male adult rats of Wistar strain, weighing about $380 \mathrm{~g}$, were used throughout the experiment which was divided into three stages of 8 days each. All the animals had been kept on the stock diet of our laboratory which consisted of $76 \%$ crushed wheat, $15 \%$ fish meal, $5 \%$ alfalfa meal, $2 \%$ soy bean oil, $2 \%$ brewer's yeast and $1 \%$ salts (sodium chloride: calcium carbonate, precipitated $=1: 2$ ), the crude protein content being $23.8 \%$ on dry basis.

In the first stage (stage $\mathbf{I}$, the following dietary groups were designed for the assay at the normal level of body protein: 20,10 and $5 \%$ levels of whole egg protein (I-E20, I-E10 and I-E5), 20\% level of casein and yeast protein (I-C20 and I-Y20) and nonprotein control (I-NP). In the second stage (stage II), all the groups were given a non-protein diet, during which time endogenous urinary nitrogen (EUN) and metabolic fecal nitrogen (MFN) were measured for the calculation of BV in the third stage (stage III). The effects of different sources and quantities of the 
preceding dietary protein on the amounts of EUN and MFN were examined at the same time in stage II. In stage III the animals were given again each protein at 20 and $5 \%$ levels for the assay under repletion, in which the animals of $20 \%$ groups (III-E20, III-C20 and III-Y20) were each assigned from the groups of E10, E5 and NP in stage I, and those of $5 \%$ groups (III-E5, III-C5 and III-Y5) from the groups of $E 20, C 20$ and $Y 20$ in stage $I$, respectively.

The non-protein diet was composed of $85.6 \%$ wheat starch, $5.00 \%$ soybean oil, $5.00 \%$ cellulose powder, $4.00 \%$ salt mixture and $0.431 \%$ vitamin mixture, details of the last three being described in a previous report. $^{6}$ In all the protein diet groups, each protein source was substituted for wheat starch of the nonprotein diet to give each designed level on the basis of nitrogen content. The nitrogen content of the casein (Kosō Chemical Co., Ltd., Tokyo) was $14.79 \%$ and that of the yeast, Candina utilis (Tôyōbōseki Chemical Co., Ltd., Osaka) $7.20 \%$, both on dry basis. All the animals were housed individually in the metabolism cage, ${ }^{7)}$ and the diet and water were given ad libitum.

Analyses of body and excreta nitrogen. Body nitrogen of the animals at the end of the experimental period was determined as previously described. ${ }^{6}$ Urine and feces during the experimental period were collected every two days and their nitrogen was determined by the Kjeldahl method. The initial body nitrogen, which was used for the calculation of percentage change in total body nitrogen, was estimated from the final body nitrogen and the nitrogen balance during the experimental period.

\section{RESULTS}

Figures 1 and 2 show that the change of body weight throughout the three stages was much irregular compared with that of total body nitrogen but giving a smaller standard error, mostly less than 3\%. I-C20, I-E20 and I-E10 gained their weight much, in descending order, followed by the nearly equivalent loss under the protein depletion in stage II. I-Y20 almost maintained the initial body weight, whereas the body weight of I-E5 was inclined to decrease and that of I-NP decreased with a pattern of sigmoidal curve.

In stage II, protein deprivation caused weight loss nearly to the same extent in all the groups. During the repletion in stage III, III-E20 and III-C20 increased their weight most, both about $6 \mathrm{~g}$ per day. III-E5 increased the weight considerably in contrast to its decrease in stage I, while III-C5 and III-Y5 were inclined to decrease their weight.

As Fig. 2 shows, on the other hand, the percentage change of total body nitrogen against each initial value showed the systematic patterns in response to the source and quantity of dietary protein giving little standard error, within $1 \%$. It should be noted that in the case of whole egg protein the amount of net nitrogen retention, as determined by the difference in total body nitrogen between each protein group and the non-protein group, was closely proportional to the levels of dietary protein. This can also be interpretated by nearly the same values of NPU among these three groups in stage I as shown later in Table III. Since the nitrogen balance of this experiment was determined by the subtraction of urine and feces nitrogen from nitrogen intake, the increase of net nitrogen retention could therefore include that of hair and the most part of skin nitrogen which are not in the so-called dynamic equilibrium of body protein metabolism. There seems to exist much of such nitrogen in I-E20 and I-C20 because, during the protein depletion in stage II, their body nitrogen did not reduce to each initial level while their body weight reduced to the initial level. The body nitrogen of I-E10 and I-Y20 as well as their body weight reduced to each initial level during that time. I-C20, which attained the maximum body weight, was inferior to I-E20 in total body nitrogen.

The body nitrogen loss in stage II occurred with exponential patterns in all groups, whose initial slopes probably indicated the content of the more labile nitrogen or reserve protein in response to the different sources and quantities of dietary protein in stage I. Because of almost identical slope angles on the 14 to 16 th days of the protein-prefed groups to that of the non-protein group, there seems to exist no longer the more labile nitrogen in those protein-prefed groups at this period. Therefore, the content of the more labile nitrogen of each protein-prefed group was estimated by a general kinetic analysis ${ }^{8)}$ from 


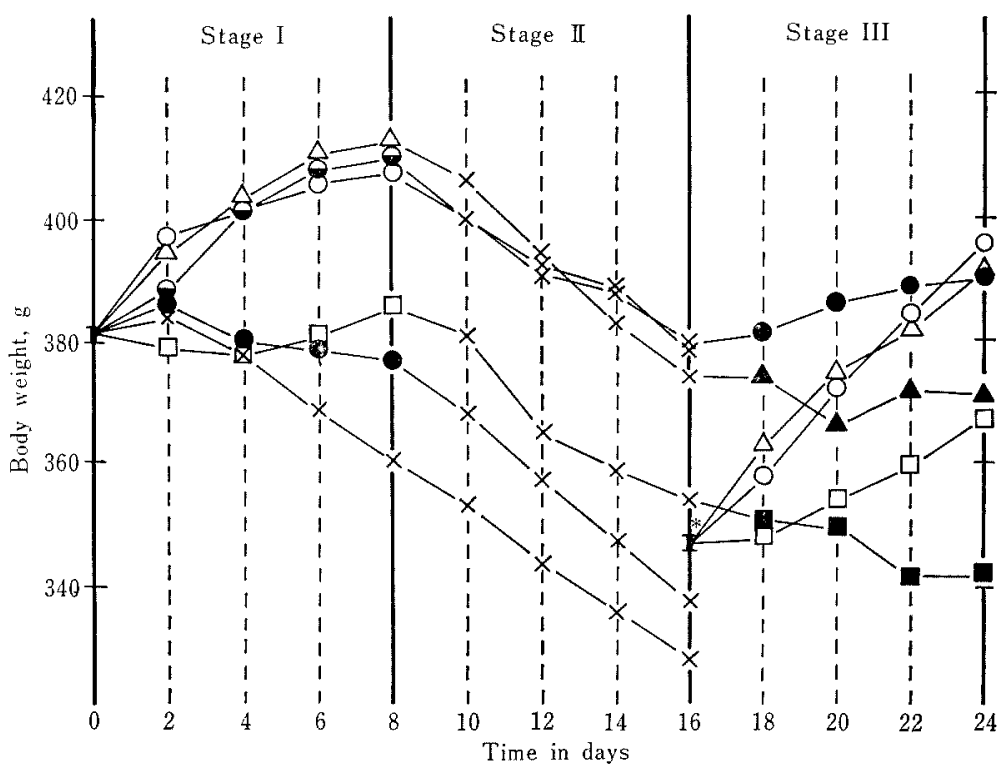

FIG. 1. Changes in Body Weight of Rats throughout Experımental Period Divided into Three Stages.

Symbols represent as follows: Non-protein group, $x$ and Protein-fed groups,
Dietary level
Whole egg protein
$20 \%$
$10 \%$
$(\mathrm{E} 10)$
$5 \%$
Casein
$\triangle(\mathrm{C} 20)$
$-$
- (E5)
Yeast protein
$\square(\mathrm{Y} 20)$
$\Delta$ (C5)
(Y5)

* The rats of these three groups were each assigned at the end of stage II from the groups of E10, E5 and NP in stage I in equal numbers respectively.

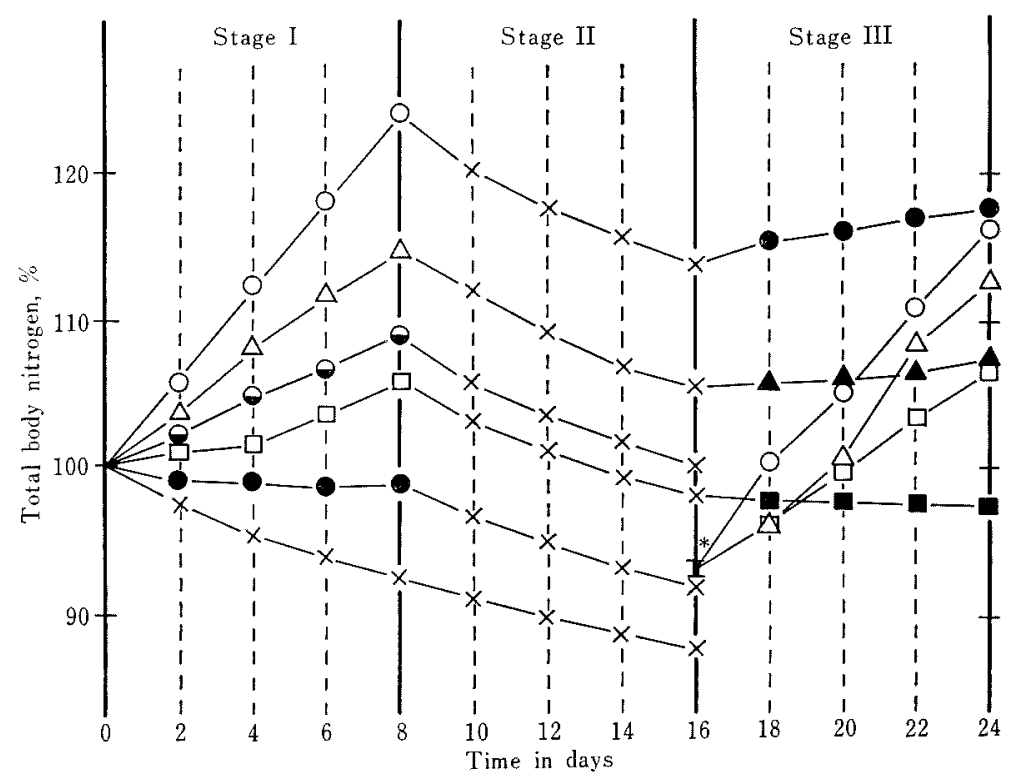

FIG. 2. Percentage Changes in Total Body Nitrogen of Rats throughout Experimental Period Divided into Three Stages.

Symbols are the same as shown in Fig. 1. 
Table II. Content of the More Labile Nitrogen (MLN) in Reference to Total Body Nitrogen of Rats in Stage I

\begin{tabular}{llcccc}
\hline & & $\begin{array}{c}\text { Proportion } \\
\text { of MLN to } \\
\text { total body } \\
\text { nitrogen } \\
(\% \%\end{array}$ & $\begin{array}{c}\text { Total } \\
\text { body } \\
\text { nitrogen }\end{array}$ & $\begin{array}{c}\text { Total } \\
\text { amount } \\
\text { of MLN }\end{array}$ & $\begin{array}{c}\text { The } \\
\text { remainder } \\
\text { (The less labile } \\
\text { nitrogen) } \\
(\mathrm{g})\end{array}$ \\
\hline Whole egg & $\begin{array}{l}20 \%(\mathrm{E} 20) \\
10 \%(\mathrm{E} 10)\end{array}$ & 2.40 & 12.20 & 0.293 & 11.91 \\
Protein & $5 \%(\mathrm{E} \mathrm{5})$ & 2.40 & 10.72 & 0.257 & 10.46 \\
Casein & $20 \%(\mathrm{C} 20)$ & 1.26 & 9.73 & 0.123 & 9.61 \\
Yeast protein & $20 \%(\mathrm{Y} 20)$ & 2.76 & 11.31 & 0.312 & 11.00 \\
\end{tabular}

Table III. Nutritive Values of Whole Egg Protein, Casein and Yeast Protein in Adult Rats at Normal Level of Body Protein and in Those after Protern Depletion

\begin{tabular}{|c|c|c|c|c|c|c|c|}
\hline & & \multicolumn{3}{|c|}{$\begin{array}{c}\text { At normal level of body protein } \\
\text { (Stage I) }\end{array}$} & \multicolumn{3}{|c|}{$\begin{array}{l}\text { After protein depletion } \\
\text { (Stage III) }\end{array}$} \\
\hline & & $\begin{array}{l}\text { True } \\
\text { digestibility } \\
\text { (TD) }\end{array}$ & $\begin{array}{c}\text { Biological } \\
\text { value } \\
(\mathrm{BV})\end{array}$ & $\begin{array}{c}\text { Net protein } \\
\text { utilization } \\
\text { (NPU) }\end{array}$ & $\begin{array}{l}\text { True } \\
\text { digestibility } \\
\text { (TD) }\end{array}$ & $\begin{array}{c}\text { Biological } \\
\text { value } \\
\text { (BV) }\end{array}$ & $\begin{array}{l}\text { Net protein } \\
\text { utilization } \\
\text { (NPU) }\end{array}$ \\
\hline \multirow{3}{*}{$\begin{array}{l}\text { Whole } \\
\text { egg } \\
\text { protein }\end{array}$} & $20 \%(\mathrm{E} 20)$ & $\begin{array}{c}89.9 \pm 1.2^{a 1} \\
(90.5 \pm 1.1)^{b 1}\end{array}$ & $\begin{array}{c}71.1 \pm 4.1 \\
(71.9 \pm 3.2)\end{array}$ & $\begin{array}{l}63.9 \\
(65.1)\end{array}$ & $91.0 \pm 0.5$ & $64.3 \pm 3.6$ & 58.5 \\
\hline & $10 \%(\mathrm{E} 10)$ & $\begin{array}{c}83.3 \pm 2.8 \\
(84.1 \pm 2.1)\end{array}$ & $\begin{array}{l}77.2 \pm 1.2 \\
(77.7 \pm 3.9)\end{array}$ & $\begin{array}{l}64.3 \\
(65.3)\end{array}$ & - & - & - \\
\hline & $5 \%($ E 5$)$ & $\begin{array}{c}73.7 \pm 2.3 \\
(71.9 \pm 4.5)\end{array}$ & $\begin{array}{c}93.2 \pm 4.2 \\
(90.8 \pm 5.7)\end{array}$ & $\begin{array}{c}68.9 \\
(65.3)\end{array}$ & $86.7 \pm 2.1$ & $99.9 \pm 1.3$ & 86.6 \\
\hline Casein & $20 \%(\mathrm{C} 20)$ & $\begin{array}{c}96.9 \pm 0.4 \\
(98.4 \pm 0.6)\end{array}$ & $\begin{array}{c}46.0 \pm 1.0 \\
(49.0 \pm 1.5)\end{array}$ & $\begin{array}{c}44.6 \\
(48.2)\end{array}$ & $98.6 \pm 0.0$ & $60.6 \pm 3.1$ & 59.8 \\
\hline \multirow{2}{*}{$\begin{array}{l}\text { Yeast } \\
\text { protein }\end{array}$} & $\begin{array}{r}5 \%(C 5) \\
20 \%(Y 20)\end{array}$ & $\begin{array}{c}- \\
76.3 \pm 0.9 \\
(74.9 \pm 1.6)\end{array}$ & $\begin{array}{c}- \\
43.4 \pm 1.7 \\
(38.6 \pm 3.4)\end{array}$ & $\begin{array}{c}- \\
33.1 \\
(28.9)\end{array}$ & $\begin{array}{l}99.7 \pm 1.8 \\
78.2 \pm 0.4\end{array}$ & $\begin{array}{l}90.0 \pm 1.3 \\
57.7 \pm 1.3\end{array}$ & $\begin{array}{l}89.7 \\
45.1\end{array}$ \\
\hline & $5 \%\left(\begin{array}{l}5 \\
5\end{array}\right)$ & - & - & - & $79.3 \pm 3.1$ & $67.3 \pm 1.1$ & 53.4 \\
\hline
\end{tabular}

a) Standard error

b) Values promptly determined for the first 4 days.

the difference between the intercept on the 8 th day of each protein-prefed group and that of the parallel regression line of the nonprotein group through the dot on the 16th day of each protein-prefed group. As shown in Table II, the contents of the more labile nitrogen of E20 and E10 gave the same value of $2.40 \%$, suggesting no greater difference in the saturation of body protein. The content of this nitrogen of $\mathrm{C} 20,2.76 \%$, was the highest of all the protein groups, showing just the same value as previously observed. ${ }^{3)}$ I-E5 gave the value of $1.26 \%$, that may imply the minimum level of the more labile nitrogen for maintenance.

During the repletion in stage III, III-E20 gained the body nitrogen most, just as much as I-E20. III-C20 and III-Y20 showed a greater nitrogen retention compared with I-C20 and I-Y20, respectively. Even III-E5 and III-C5 were evidently in positive nitrogen balance, and III-Y5 was just in nitrogen equilibrium. Thus the nutritive values of dietary protein during the repletion after protein deprivation can be much different from those for maintaining the normal level of body nitrogen.

Table III shows TD, BV and NPU of the three proteins determined in stages $\mathrm{I}$ and III. In stage I, EUN and MFN were estimated by the urinary and fecal nitrogen of I-NP for 8 days, respectively. NPU which was determined as the product of TD and BV is therefore fundamentally equivalent to that designat- 
Table IV. Relative Net Nitrogen Retention (R-NNR) and Relative Net Protein Utilization (R-NPU) of Casein, and Yeast Protein in Stages I and III, Taken Whole Egg Protein as 100

\begin{tabular}{|c|c|c|c|c|c|}
\hline & & \multirow{3}{*}{$\begin{array}{c}\begin{array}{c}\text { Relative net } \\
\text { nitrogen } \\
\text { retention }\end{array} \\
\text { Stage I } \\
\left(\mathrm{R}-\mathrm{NNR}_{20}\right)\end{array}$} & \multicolumn{3}{|c|}{$\begin{array}{l}\text { Relative net } \\
\text { protein utilization }\end{array}$} \\
\hline & & & \multirow{2}{*}{$\frac{\text { Stage I }}{\left(\mathrm{R}-\mathrm{NPU}_{20}\right)}$} & \multicolumn{2}{|c|}{ Stage III } \\
\hline & & & & $\left(\mathrm{R}-\mathrm{NPU} \mathrm{U}_{20}\right)$ & $\left(\mathrm{R}-\mathrm{NPU}_{5}\right)$ \\
\hline \multirow{3}{*}{ Whole egg protein } & $20 \%$ (E20) & $(100)^{a !}$ & $(100)$ & $(100)$ & - \\
\hline & $\{10 \%(\mathrm{E} 10)$ & 52 & 96 & - & - \\
\hline & $(5 \%(\mathrm{E} 5)$ & 20 & 109 & - & $(100)$ \\
\hline \multirow{2}{*}{ Casein } & $20 \%(\mathrm{C} 20)$ & 71 & 67 & 102 & - \\
\hline & $\{5 \%(\mathrm{C} 5)$ & - & - & - & 104 \\
\hline \multirow{2}{*}{ Yeast protein } & $20 \%(Y 20)$ & 43 & 51 & 77 & - \\
\hline & $5 \%(Y 5)$ & - & - & - & 62 \\
\hline
\end{tabular}

a) Taken as 100 for relative representation.

ed as the body nitrogen method by Bender and Miller, ${ }^{9}$ except the dermal loss of nitrogen and the difference in the correction method of EUN and MFN as described below. EUN and MFN for calculating TD and BV in stage III were estimated in individual rats to be four times the urinary and fecal nitrogen on the 15 to 16 th days respectively, because the excretary nitrogen on these days in all of the proteinprefed groups was similar to that of the nonprotein group showing no influence of the previous protein intake. NPU in stage III was also determined by multiplying TD by BV. The estimation of MFN both in stages $I$ and III was corrected in proportion to food consumption and that of EUN in stage $I$ to the initial body weight.

In stages I and III, TD of E20, C20 and Y20 showed approximately the same values. The different levels of protein intake, 20 and $5 \%$ of diet, did not much influence on TD of the three proteins in stage III. TD of the whole egg protein in all cases was possibly lowered to some extent, because the coarse grains in the sample which arose from lack of crushing was found undigested in feces. Later experiments in our laboratory have usually given TD of 90 to $95 \%$ to the finely powdered samples of this protein.

BV determined at $5 \%$ level of dietary protein in stage III, which is generally considered to be the standardized assay condition, gave 99.9 for whole egg protein, 89.2 for casein and
64.1 for yeast protein. These values are in good agreement with those hitherto accepted by many workers. BV of nearly 100 for the newly prepared whole egg protein afforded an advantage to the protein as a standard reference. BV at $20 \%$ level of the three proteins in stage III naturally gave the lower values than those at $5 \%$ level, where the differences in values among the protein sources were made less noticeable.

The higher values of $\mathrm{BV}$ and NPU for C20, $\mathrm{Y} 20$ and $\mathrm{E} 5$ in stage III than in stage I were clearly indicated, whereas BV and NPU for E20 were lower to the contrary. This may be attributed to the specific effect of egg protein for sustaining the extracellular or other protein components besides the ordinary intracellular protein at the normal level of body protein, possibly due to the higher content of sulfurcontaining amino acids.

In Table IV the relative net nitrogen retention (R-NNR) and the relative efficiency of dietary protein for this nitrogen retention, i.e., the relative NPU ( $\mathrm{R}-\mathrm{NPU})$ were shown for casein and yeast protein taking the values of whole egg protein groups as 100 . It is clear that I-C20 and I-Y20 saturated only 71 and $43 \%$ levels of I-E20 for net nitrogen retention respectively and their R-NPUs were far less than those obtained in stage III. Thus the evaluation of dietary proteins at the normal level of body protein, in which the metabolism of the more labile protein or 
reserve proteins is possibly more reflected, was much different from that during the repletion after protein deprivation.

R-NNR and R-NPU of I-E10 and I-E5 were also given in the same table taking I-E20 as a standard. The fact that their R-NNRs are rather proportional to the dietary protein level accompanied with nearly constant R-NPUs was clearly shown.

\section{DISCUSSION}

There have been several reports on the relative evaluation of dietary proteins by use of whole egg protein. Egg-replacement value ${ }^{10)}$ and chemical score ${ }^{11,12}$ are the well-known methods using the egg protein or its essential amino acid pattern as a standard reference. However, the samples of egg protein used for nutritional experiments have generally been limited to the raw material, the heat-coagulated one, and the dried and/or defatted one, whose protein contents being approximately 13, 50, and 40 to $80 \%$, respectively. In some cases egg albumin was used instead of whole egg protein. For this reason, the non-protein components and the indefinite nature of egg protein itself might have exerted unfavorable influence on nutritional studies.

The whole egg protein prepared in this study had the purity of $96.5 \%$ and gave nearly the maximum biological value, 99.9 , for adult rats, having the similar amino acid composition to that listed in the recent table of FAO. Moreover, the simple procedure made it possible to prepare about $500 \mathrm{~g}$ of the whole egg protein from about $5 \mathrm{~kg}$ of raw eggs in one day with a protein recovery of $95 \%$. The high purity may be attributed to the succesive extractions with organic solvents and water in wet state throughout the preparation. The initial extraction with boiling ethanol is considered to be most effective for the elimination of various lipids, especially those of lipoproteins in the yolk, accompanied with the sufficient coagulation of egg protein that prevent the protein loss in filtrates. Later experiments in our laboratory on the nutritive values of the same sample for growing rats gave 4.2 and 5.2 for PER, 95 and 94 for TD, 98 and 95 for $\mathrm{BV}$, and 93 and 86 for NPU at $10 \%$ dietary level. ${ }^{13}$ ) Thus the prepared whole egg protein was qualified as a standard reference.

The net nitrogen retention herein mentioned is the actual level of retained body nitrogen which possibly denote, for the most part, metabolically active or labile proteins in the case of adult animals. The relative representation of this value to that at $20 \%$ dietary level of whole egg protein seems to roughly indicate the percentage saturation of such a protein, because it has been found that the $20 \%$ whole egg protein diet secures the maximum retention of body protein. ${ }^{14,15)}$ In ordinary assay, such a nitrogen retention has not generally been referred besides the efficiency of protein utilization. Therefore, the protein evaluation hitherto conducted has not been sufficiently correlated to the metabolically active or labile proteins that essentially concern with the socalled protein reserves or physiological functions of the animal.

Since the net nitrogen retention is the product of efficiency and protein intake, R-NNR is equivalent to R-NPU in the same protein intake. However the protein intake without food restriction is suggested to be another reflection of protein quality relating to the efficiency of the protein in the body and also of physiological effects, apart from the taste of the diet. As shown in Table IV, for example, R-NNRs of I-C20 and I-Y20 was different from their R-NPU respectively, and I-E10 gave the greater R-NNR than I-Y20 did regardless of the fact that the former R-NNR was less than twice the latter R-NPU. It may be valuable that the conventional protein evaluation, including the requirements of essential amino acids, should be concerned with the relative net nitrogen retention.

As has generally been discussed, the relative evaluation by use of a reference protein has the advantage to minimize the experimental deviation due to the different assay conditions. Especially the relative NPU does not seem 
to be influenced by the experimental period. Our later experiment ${ }^{16}$ ) on weanling rats for 24 days gave the relative NPU of 74 for casein regardless of its actual NPU of 28.3 .

BV and NPU have been determined in different ways not only of the assay conditions but also of the method of calculation or expression. As for $\mathrm{BV}$, the preceding dietary condition, food intake, estimation of EUN and MFN, and correction of metabolized nitrogen for metabolic size have not been consistent, and as for NPU, the calculated value defined as the product of $T D$ and $B V$, which has commonly been used, inevitably induce much different experimental conditions from those originally defined by Bender and Miller. ${ }^{9}$ This report showed that BV and NPU are much variable at the different levels of initial body nitrogen of the tested animals.

Although there might be several groups of body protein with respect to metabolic activity or lability in response to dietary protein levels, at least the following three components seem to be concerned with the present study: (A) the metabolically active extracellular nitrogen, which is easily retained, but not easily catabolized in protein depletion, (B) the more labile nitrogen or reserve protein as designated by the extra nitrogen excretion at the initial stage of protein depletion, and (C) the less labile nitrogen, the ramainder. Hair, most part of skin and collagen in the connective tissue are considered to be component A. The possible increase of this component was shown for I-E20 and I-C20 as mentioned before. This increase seems to occur to the greater extent with the more intake of dietary protein, especially of good quality. The greater rate of nitrogen retention than that of weight gain was also observed in the adult rats fed on amino acid mixtures with highly increased additions of individual deficient essential amino acids, where the different rates of nitrogen retention were shown for the different amino acids. ${ }^{17)}$ It has been accepted that the greater nitrogen retention by the conventional nitrogen balance method than by the body nitrogen method is, in part, attributed to the dermal loss of such a nitrogen component.

In the preceding paper, ${ }^{8>}$ the content of component B in the adult rat fed a $20 \%$ casein diet was estimated to be about $2.8 \%$ of total body nitrogen, and in the present experiment its content was shown to range from 1.26 to $2.76 \%$ with the different sources and levels of dietary protein, the value for $20 \%$ casein being identical in both experiments. The contents of this component in liver and muscle were also estimated to be 30.6 and $6.6 \%$ of each total nitrogen, respectively, in the above paper.

Component $\mathrm{C}$ is, for the most part, the ordinary tissue proteins that sustain normal body functions of the animal. Our previous experiment ${ }^{18)}$ showed that in the adult rats the myofibrillar or contractile protein of muscle, together with its sarcoplasmic protein, decreased exponentially in the earlier stages of protein depletion, representing the less labile component in absolute amount.

Since the body nitrogen of I-E20 at the end of stage I (on the 8th day) decreased by $8.0 \%$ during stage II and component $\mathrm{B}$ is suggested to disappear completely during that time, the ratio of component $\mathrm{B}$ : $\mathrm{C}$ among the lost nitrogen during stage II could be estimated to be $2.4(\%): 5.6(\%)=3: 7$. Therefore, the nutritive values of dietary protein determined after protein depletion might be more represented by the retention efficiency for component C. On the other hand, the nutritive values at the normal level of body nitrogen seems to represent the retention efficiency for component $B$ to greater extent, because the ratio of component $\mathrm{B}$ : $\mathrm{C}$ on the first day of protein depletion is approximately $3: 1$ as previously reported. ${ }^{8)}$

Component A appears much more significant in the assay at the normal level of body protein, because, during the repletion, animals could not afford to provide so much nitrogen to component $\mathrm{A}$ taking preference to components $\mathrm{B}$ and $\mathrm{C}$. For these reasons, the nitrogen retention and its efficiency can vary at the different levels of body protein of animals. 


\section{REFERENCES}

1) "Evaluation of Protein Quality," National Academy of Science-National Research Council, Publication No. 1100, Washington, D.C., 1963.

2) S. Moore, J. Biol. Chem., 238, 235 (1963).

3) R. D. Greene and A. Black, ibid, 155, 1 (1944).

4) K. Bailey, Biochem. J., 31, 1406 (1937).

5) "Amino-acid Content of Foods and Biological Data on Proteins," Food and Agriculture Organization of the United Nations, Rome, 1970, p. 122.

6) Y. Yamaguchi and M. Kandatsu, Agr. Biol. Chem., 37, 579 (1973).

7) Y. Yamaguchi and M. Kantatsu, J. Japan Biochem. Soc., 33, 549 (1961).

8) Y. Yamaguchi and M. Kandatsu, Nature, 217, 668 (1968).

9) A. E. Bender and D. S. Miller, Biochem. J., 53, vii (1953).
10) J. R. Murlin, E. S. Nasset and M. E. Marsh, $I$. Nutrition, 16, 249 (1938).

11) H. H. Mitchell and R.J. Block, J. Biol. Chem., 163, 599 (1946).

12) "Protein Requirements," FAO and WHO, WHO Technical Report Series No. 301, Geneva, 1965, p. 45.

13) M. Yamaguchi, H. K. Hwang and M. Kandatsu, VIIIth Int. Congr. Nutrition, Prague, Abstracts of Papers, Y-1 (1969).

14) H. H. Mitchell and J. R. Beadles, J. Nutrition, 47, 133 (1952).

15) H. Tanaka, M. Yamaguchi and M. Kametaka, Agr. Biol. Chem., submitted.

16) M. Yamaguchi and M. Kandatsu, unpublished.

17) E. P. Benditt, R. P. Woolridge, C. L. Steffee and L. E. Frazier, J. Nutrition, 40, 335 (1950).

18) M. Yamaguchi and M. Kandatsu, Agr. Biol. Chem., 31, 1372 (1967). 